\title{
“O PRESENTE É UM PRESENTE": IMAGINÁRIO, DESEJO E IDENTIDADES POLÍTICAS NO BRASIL ${ }^{1}$
}

\author{
"THE PRESENT IS A PRESENT": \\ IMAGINARY, DESIRE AND POLITICAL IDENTITIES IN BRAZIL
}

Gustavo Said $^{2}$

RESUMO: O objetivo desse texto é discutir a formação do imaginário e a reconfiguração das identidades individuais e coletivas na sua relação com o desejo, no bojo das manifestações políticas no Brasil, compreendendo o conturbado período de 2013 a 2018. O recorte temporal expresso, contudo, serve apenas para efeitos analíticos, pois o imaginário deve ser pensado numa perspectiva histórica que não se resume a uma matriz de tempo contínuo. A premissa orientadora da reflexão proposta - a de que ao imaginário subjaz a produção e a circulação de imagens por meios técnicos, mas também a atividade de imaginação psíquica - revela a indissociabilidade entre o imaginário, as tramas da memória e as imposições da pulsão escópica, quer dizer, os imperativos do ver e ser visto. Assim, no plano teórico, procura-se evitar tanto a discussão sobre o imaginário que não contempla uma teoria da imagem, sob quaisquer perspectivas, quanto o tratamento da imagem de forma reificada, numa abordagem que celebre a autonomia de seu estatuto, à margem do imaginário, ou seja, de processos mnemônicos, sociais e culturais que lhe sustentam e lhe conferem sentidos. Para tanto, busca-se aproximar a psicanálise, a filosofia da história de Walter Benjamin e as teorias do imaginário e da imagem. Consoante à visada teórica adotada, tenta-se superar a operação metodológica que trata as imagens apenas como um texto, em parte uma herança da tradição filosófica (platonismo) que via nas imagens uma deturpação, cópia imperfeita ou sombra das ideias imutáveis. O texto está dividido em sete seções, cada uma aludindo a imagens ou a fragmentos de textos que, ressalve-se, tem valor de imagem.

Palavras-chave: Imaginário. Política. Desejo. Identidades

ABSTRACT: The purpose of this paper is to discuss the formation of the imaginary and the reconfiguration of individual and collective identities in their relation to desire, in the midst of political manifestations in Brazil, comprising the troubled period from 2013 to 2018. The expressed time frame, however, is for analytical purposes only, because the imaginary must be thought of in a historical perspective that is not limited to a continuous time matrix. The guiding premise of the proposed reflection - that the imagination underlies the production and circulation of images by technical means, but also the activity of psychic imagination - reveals the indissociability between the imaginary, the plots of

\footnotetext{
1 Versão revisada e modificada do texto apresentado no Ciseco 2018, em Japaratinga-AL.

2 Doutor em Ciências da Comunicação pela Unisinos. Departamento de Comunicação Social - Programa de Pós-Graduação em Comunicação - UFPI.
} 
memory and the impositions of scopic drive, that is, the imperatives of seeing and being seen. Thus, at the theoretical level, we try to avoid both the discussion about the imaginary that does not contemplate a theory of the image, from any perspective, as the treatment of the image in a reified way, in an approach that celebrates the autonomy of its statute, in the margin of the imaginary, that is, of mnemonic, social and cultural processes that sustain and give meaning to it. To this end, we seek to approach psychoanalysis, Walter Benjamin's philosophy of history and the theories of the imaginary and the image. Depending on the theoretical approach adopted, we try to overcome the methodological operation that treats images only as a text, in part a legacy of the philosophical tradition (Platonism) that saw in images a misrepresentation, imperfect copy or shadow of immutable ideas. The text is divided into seven sections, each alluding to images or text fragments that, it should be noted, have image value.

Key-Words: Imaginary. Politics. Desire. Identities

\section{INTRODUÇÃO}

No bojo das manifestações políticas no Brasil, compreendendo o conturbado período de 2013 a 2018, destacam-se dois aspectos intimamente relacionados, a saber: a produção de imaginários e a reconfiguração das identidades individuais e coletivas. Assim, sobre o esteio das idealizações requeridas e das vinculações identitárias daí emanadas, podese inferir que, durante o período aludido, as estratégias políticas voltadas ao controle do imaginário se coadunaram à regulação simbólica e procuraram negar à pulsão ligada à imagem sua relação dual com a alteridade.

Essa trama imaginário-simbólica desembocou em práticas próximas à violência e ao fanatismo, nas quais fica clara a relação densa do sujeito com o significante, como pressupõe a psicanálise lacaniana. Nessa obsessão, o sujeito, preso às idealizações de vínculo, se posiciona contra toda ambiguidade constitutiva, aspirando a uma suposta unidade identitária. Orbitando os signos dos acontecimentos com incerteza, o sujeito tenta inferir apressadamente o real, com precisão e clareza, sem variações. Em outras palavras, busca significantes com que sonha capturar o real - neurose de traço obsessivo que se mostra na defesa compulsiva de uma ideia e na recusa de qualquer outro argumento ou referente do real. Nesse caso, tanto faz se se divulga notícia verdadeira ou fake news: a paixão compulsiva pela verdade equivale à crença apaixonada na mentira. 
Assim é que, no escopo da ação política das manifestações de 2013 a 2018, vai se delineando um campo de visibilidade e de parâmetros de identificação, reafirmando o imaginário como um subdito da função simbólica. Eis um elemento de costura entre as diversas manifestações em análise: a relação entre visibilidade, estética e política, a indissociabilidade entre política e identidade, pois a gênese da política se situa no conflito sobre a configuração do mundo sensível (Jacques Ranciere, 2008). Em todas as manifestações do período em análise é visível a disputa por e no imaginário. Disputa pelo poder, ou seja, por produção, agenciamento, significação e valorização de imagens, conforme apregoa a consagrada assertiva de Dominique Colas de que toda imagem do poder se funda no poder da imagem.

Como o imaginário é o lugar da identificação (o Eu é corporal, já dizia Freud; para Lacan, o Eu é imaginário), compreende-se que não há relação fora da imagem e que a produção de imagem é uma ação política, de relação com o 'outro', de assunção da diferença e de construção de um lugar (simbólico) de pertença. A imagem produzida é, no fundo, a imagem suposta de si mesmo, uma idealização do eu, para efeitos de reconhecimento pelo 'outro', por um grupo. Quando, no entanto, esse 'outro' assume a conotação de um 'mesmo', uma nova economia de identificação se instala, rompendo as amarras simbólicas de uma solidariedade mais geral fundada em princípios de racionalidade democrática e de diversidade cultural, daí decorrendo uma divisão identitária radical, na qual o 'outro', o diferente, passa a ser o inimigo. Nasce desse sentimento a defesa de práticas punitivas, exclusivistas e marginalizadoras, muitas vezes supostamente legitimadas pela alusão a princípios legais e constitucionais reguladores da ordem sócio-simbólica.

Bronislaw Baczko (1991) observa que durante conflitos a imaginação poderá sofrer um ímpeto particular, ocorrendo uma produção acelerada de significações para os acontecimentos. É como se o símbolo se tornasse pequeno e insuficiente para nomear os acontecimentos, mas, por conta desse hiato interpretativo, não menos necessário. Marcia Espig (2004), comentando o pensamento de Baczko, avalia que o sucesso da dominação simbólica dependerá do controle dos circuitos de produção e difusão dos imaginários sociais pelos poderes constituídos, ainda que de forma restrita, pois só funcionará quando repousar sobre uma identidade de imaginação, quando fizer sentido para a comunidade à qual se dirige.

A idealização de imagens que promovem a fantasia de identificação plena e de completa coesão dos sujeitos promove em algumas comunidades e grupos a negação de qualquer plurivocidade constitutiva e, por conseguinte, a recusa da alteridade, a 
desqualificação de sentimentos, opiniões e argumentos diferentes e/ou divergentes. O que importa é selar a crença, estabelecer a verdade e sentir-se parte de um grupo, a despeito de qualquer argumento contrário ou crítica.

Dito isso, pretende-se, com esse texto, discutir o imaginário e a reconfiguração das identidades individuais e coletivas na sua relação com o desejo. O recorte temporal aqui expresso, contudo, serve apenas para efeitos analíticos, pois o imaginário deve ser pensado numa perspectiva histórica que não se resume a uma matriz de tempo contínuo. Por conseguinte, a premissa orientadora da reflexão proposta - a de que ao imaginário subjaz a produção e a circulação de imagens por meios técnicos, mas também a atividade de imaginação psíquica - revela a indissociabilidade entre o imaginário, as tramas da memória e as imposições da pulsão escópica, quer dizer, os imperativos do ver e ser visto. Assim, no plano teórico, procura-se evitar tanto a discussão sobre o imaginário que não contempla uma teoria da imagem, sob quaisquer perspectivas, quanto o tratamento da imagem de forma reificada, numa abordagem que celebre a autonomia de seu estatuto, à margem do imaginário, ou seja, de processos mnemônicos, sociais e culturais que the sustentam e lhe conferem sentidos. Consoante à visada teórica adotada, tenta-se superar a operação metodológica que trata as imagens apenas como um texto, em parte uma herança da tradição filosófica (platonismo) que via nas imagens uma deturpação, cópia imperfeita ou sombra das ideias imutáveis. As imagens tem precedência sobre o sentido lançado sobre as mesmas, o que leva a crer que, em se tratando de uma perspectiva psicanalítica, o imaginário antecede o simbólico, mas, quase sempre, o percurso metodológico leva a tecer sua significação social a partir desse último.

Feito esse breve preâmbulo de cunho teórico, é preciso aceitar o desafio que a proposta encerra nas sete seções desse ensaio, cada uma aludindo a imagens ou a fragmentos de textos que, ressalve-se, tem valor de imagem. Para tanto, busca-se aproximar a psicanálise, a filosofia da história de Walter Benjamin e as teorias do imaginário e da imagem. Assume-se, conquanto, o risco que, a título de revisionismo, o diálogo entre distintos autores e diferentes áreas pode suscitar, sobretudo em termos de releitura conceitual.

\section{1a CENA: “A ORBITAL DE POSSIBILIDADES DOS ACONTECIMENTOS ESTÁ ABERTA"}

Para evitar um encadeamento lógico de argumentos, à maneira de uma sucessão linear de imagens que não condiz com a dinâmica do imaginário, comece-se com 'um 
depois'. A pichação expressa no título dessa sessão foi feita após os protestos de junho de 2013, num muro de terreno baldio da zona Leste de Teresina (PI). É preciso analisar essa pichação (e outras citadas na sequência) extrapolando os sentidos evocados pelo texto verbal, uma vez que ela reúne elementos variados (o grafismo, a cor da tinta, o muro, o terreno, o entorno etc) que, ao modo de uma Gestalt, aludem para suas variações semânticas. Frise-se, entretanto, por força dos limites de redação e publicação desse ensaio, seu pormenor verbal - e as imagens que isso suscita.

De aspecto alegórico, numa remissão a Benjamim, dado que, nesse caso, o sentido sempre passa ao largo de um suposto núcleo de significação densa, rígida e absoluta, a incerteza transita na órbita de imprevisíveis acontecimentos: a frase da pichação evoca imagens que traduzem uma desconcertante gama de possibilidades - políticas, identitárias e, sobretudo, imagéticas - e, por outro lado, revela a inércia intelectual, jornalística e política que assolou o Brasil durante boa parte daqueles protestos. Inércia inescapável, pois se estava diante de um lampejo do imaginário, um instante fraturado do presente, um recuo nos padrões de identificação vigentes, um vácuo interpretativo. Uma ansiosa explicação representava um risco de turvação dos sentidos abertos ao porvir dos acontecimentos, já que a orbital concentrava todas as possibilidades de imaginação. Neste(s) sentido(s), os acontecimentos a que se refere a pichação produzem imagens incertas de futuro, desencadeadas por um antes que ainda não foi interpretado ou nomeado e ao qual será inevitável retroceder - em imagens, via memória! - se se pretende um exercício de historiografia. A pichação alude ao futuro com o olhar voltado aos resíduos do passado. Até então, não se falava em Jornadas de Junho. Faltava um nome ao acontecimento. Algo estava por vir.

O acontecimento é esse vir (ou ver?) a ser, puro devir, expressão do desejo informe e latente. Ele evoca a memória, reagrupa tramas narrativas do passado e do presente, reata os nós das temporalidades, produz histórias. O acontecimento é excessivo, é incontrolável, pois saturado de agoras. Na pichação mencionada há uma dupla presença que, contudo, não denota antagonismos: tradição e progresso, continuidade e mudança realçam o jogo dialético entre temporalidades. Até aquele momento, os protestos de junho de 2013 tinham a força de um acontecimento, obrigando a uma constante reelaboração semiótica.

Promovendo o retorno da atividade política para os espaços públicos, como avenidas, praças e ruas, ainda que a gestação dos protestos tenha ocorrido nas mídias sociais, Junho de 2013 pode ser entendido, segundo Albuquerque et al. (2014), como um acontecimento que enreda: a) subjetividades afoitas pela produção de algo de caráter 
público e coletivo, a composição multitudinária de lutas minoritárias; b) uma exposição de desejos não manifestos até aquele momento e uma vontade incontida de intervir e fazer política por meio da contestação e da produção de outros espaços e das consequentes relações estabelecidas entre tais subjetividades e os antigos territórios, agora ressemantizados; e c) uma espécie de atualizador da história pela subversão da língua reconhecida e pela perda do sentido primordial dos símbolos utilizados. Para Machado, Lima e Regattieri (2015), recuperando Hannah Arendt, Junho de 2013 pode ser considerado um acontecimento que satura nas ruas um campo operatório a partir da pluralidade das diferenças, um entrelaçamento de desejos em disputa com toda forma de naturalização, normalização e unificação. Acrescente-se, evocando mais uma vez Benjamin: uma alegoria de Brasil.

No plano epistemológico, as manifestações de 2013 impunham um pensamento em devir para acompanhar o processo em curso. Suspender os protocolos do passado e abrirse para a obscuridade de um futuro sem garantia, que obriga a inventar novos conceitos (Teixeira, 2014).

Não obstante, metodologicamente, ainda que o imaginário exceda as formas e também a materialidade das imagens icônicas, constituindo-se dinamicamente entre a suposta objetividade das mesmas e o processo imaginativo de ordem psíquica, é preciso se debruçar sobre a visualidade sígnica de certos acontecimentos, sobretudo sobre as imagens produzidas e circulantes, para tecer alguns exercícios de compreensão. Cumpre esclarecer que, uma vez que não se pode seccionar o imaginário, separando algumas imagens de outras e restringindo algumas delas aos contextos em que são produzidas e circulam, o recorte apresentado nesse texto serve para uma demanda específica de análise.

Com efeito, uma breve visada ao conjunto das imagens que circularam recentemente nos meios de comunicação e nas mídias sociais permite perceber como alguns conteúdos e temas reapareceram no imaginário político, acionando os mecanismos e as diversas temporalidades da memória individual e coletiva e produzindo releituras dos acontecimentos e contextos em que se inserem, à guisa de uma montagem ou edição, tal qual postulava Benjamin (2006) ao se referir ao cinema. Neste sentido, a imagem assume um valor heurístico, muito além da compreensão positivista que a reduz exclusivamente aos seus temas, conceitos ou conteúdos. Explica George Didi-Huberman (2015a, p.16): "diante de uma imagem - por mais recente e contemporânea que seja -, ao mesmo tempo o passado nunca cessa de se reconfigurar, visto que esta imagem só se torna pensável numa 
construção da memória." Muito antes, em 1915, Freud (2010) havia ponderado que somente a lembrança pode inscrever antigos traços do psiquismo em novas imagens.

Muito mais do que um repositório e/ou um repertório de imagens, o imaginário deve ser entendido como processo mnemônico criativo, lacunar, não determinista, sempre alocado no instante da experiência, mas calcado em memórias pessoais, por sua vez produtoras de associações imagéticas que ultrapassam a ideia de linearidade temporal. Se uma legibilidade histórico-social é possível, isso acontece porque as imagens não se reduzem ao seu conteúdo e desafiam um tipo de experiência baseada na objetivação do olhar, da contemplação e do pensamento, possibilitando uma imprevisível articulação entre temporalidades e produzindo uma dialética do instante perceptivo: olhar, criar e recordar uma imagem é como retroceder alguns passos e ao mesmo tempo caminhar para frente. Se tal atitude comporta uma orientação metodológica, essa deve se pautar na ideia de que não é apenas a memória que evoca imagens, mas também o contrário: ao evocar memórias pessoais, produzindo associações com outras imagens, cada imagem se torna um índice histórico que só pode ser lido se se compreende o tempo em que foi gestada (DidiHuberman, 2010) e, acrescente-se, as relações entre os sujeitos que a produziram. Essa, portanto, sua feição histórica e intersubjetiva.

É chegado o momento, então, em que as imagens começam a falar.

\section{2 a CENA: ADORMECIDO EM BERÇO ESPLÊNDIDO}

Muito se especulou sobre Junho de 2013: o encontro de identidades plurais; a substituição da política representativa indireta pela ação colaborativa nas redes; o momento em que a favela desceu o morro e a classe média deixou o Facebook; a coadunação de espaços variados (ruas e redes) nos quais diversos tempos se fizeram presentes. De fato, os protestos provocaram um hiato político-semântico e uma pressa pelo preenchimento dessa lacuna. Se as imagens alegóricas transmitiam a ideia de puro devir e ampliavam o espectro de sentidos, os símbolos que a partir dali seriam evocados tanto podiam abrir-se em novas espirais semânticas quanto fechar-se em significados fixos e rígidos, uma tentativa de encaixe em modelos compreensivos articulados à prática política vigente - e criticada.

Pensado como dimensão do social, contudo, o imaginário pode reagrupar no presente distintas constelações de sentido, sejam aquelas que vigoraram no passado recente quanto as de um período mais remoto, que, por suas pistas e seus vestígios, se tornam reveladoras de uma economia do desejo. O imaginário, na sua feição sintomática, constitui 
uma chave de leitura dos sujeitos, dos laços constituídos por eles e, logo, do contexto sócio-histórico.

"Pouco cartaz para muito problema. O Brasil acordou", escreveu um manifestante. Texto dúbio, a expressar na primeira parte que não há palavra que abarque o conjunto diversificado das demandas e subsuma o inexprimível desejo de mudança, mas ao mesmo tempo a denotar na sua simbologia (o país que dormia e agora está desperto) um gesto rotulado de inclinação política. Pouco depois, nas manifestações de 2014, essa mesma operação semântica se repetiu nas inúmeras imagens de um gigante que acabara de sair de sua letargia: O Gigante Acordou. Como pano de fundo da imagem do gigante desperto e de suas correlações simbólicas, sobressaem efeitos de sentido similares amparados na linearidade do tempo lógico: a) passar o país a limpo, implicando na aceitação de um passado sujo; b) o Brasil é daqui para frente, sugerindo que o passado do país é condenável; c) o futuro é a partir de agora, indicando a ideia de marco histórico, de que a história se reescreve hoje. O que é muito interessante e sintomático, entretanto, é que essa operação simbólica de cunho político-partidário também esteve presente no bordão da esquerda brasileira em sua feição lulista: "nunca antes na história desse país".

A crença de que o passado é condenável e de que o futuro redimirá o país recupera o discurso salvacionista, de cunho religioso, que desembocou, durante a eleição de 2018, numa forma de coesão grupal com requintes de fanatismo, proclamando o enterro dos partidos e o fim da história política. Tanto o 'nunca antes nesse país' quanto 'o gigante acordou' reafirmam o tempo linear e lógico que se quer impetrar ao imaginário, com suas narrativas salvacionistas baseadas numa decisão e numa escolha divinas sobre os rumos do país. Não sem efeito, nos eventos da campanha presidencial de 2018 é que se vê mais claramente o estatuto político de tais operações simbólicas, sobretudo a tentativa de substituir no imaginário o regenerado mito do pai dos pobres pelo consagrado - em outras épocas - mito do salvador da pátria. O Brasil, como imagem de um barco a deriva que necessita encontrar o porto-seguro de uma promessa nunca antes cumprida, entrega-se nas mãos de um Capitão. Não há imagem mais apelativa nesse sentido do que aquela que circulou em redes sociais e que trazia Jesus Cristo resgatando o candidato Jair Bolsonaro de um afogamento: "Segure em minha mão, Capitão, ainda temos que salvar um país inteiro". Não por acaso, o lema do candidato durante a campanha foi "Brasil acima de tudo, Deus acima de todos", cujo contrapeso podia ser visto, no mesmo período, noutra pichação num muro de terreno particular em Teresina, na qual se podia perceber a crítica a valores e, 
sobretudo, de sentidos anunciada pela aposta niilista da morte de Deus: "Brasil acima de nada. Deus nem existe."

\section{$3^{a}$. CENA: DEUS E O DIABO NA TERRA DO SOL}

Antes, porém, da campanha presidencial de 2018, o espectro simbólico conferido aos protestos já havia se insinuado nas propagandas do Governo de Dilma Roussef. Nessa contraofensiva institucional, as imagens de cunho religioso pressupunham uma reorganização em torno de um único sentido: à existência de Deus corresponde a imagem do Brasil como uma terra afortunada. Nas peças de propaganda, a onipresença da imagem do Cristo Redentor, por exemplo, atestava a crença de que Deus é, de fato e de direito, brasileiro, sendo esse, por derivação, um povo abençoado - e ordeiro e cordial, acrescentese.

Se, por um lado, o ufanismo das campanhas governamentais justificava a realização da Copa do Mundo de 2014, por outro, os partidos de oposição direcionavam unilateralmente os protestos contra a então Presidente e seu partido, o que demonstrava uma arregimentação de forças políticas e uma divisão de eleitores em dois grupos distintos, sectários, rivais e irreconciliáveis, sustentados na contradição de opiniões, processo agravado nas preleções do impeachment durante os anos de 2015 e 2016. Naquele momento, as imagens indicavam mais claramente seu devir simbólico. O caráter pulsional do imaginário, a partir dali, tinha para onde se dirigir. Estava em curso uma ação políticopartidária.

Cumpre esclarecer que o aspecto político do imaginário se refere à sua dinâmica pulsional, pois o desejo da imagem, que é desejo de objeto, tem a ver com a regulação dos corpos e das ideias. Para Mondzain (2017, p.48), a domesticação dos desejos na sua relação com a produção de imagens traduz uma dimensão política: "Sendo reconhecidas como produções libidinais, as imagens não tem sido de fato imediatamente o objeto de uma meditação sobre o tratamento político do desejo nem sobre o destino das pulsões no coração da cidade." Por trás das imagens, não apenas uma experiência do tempo, da história, mas a expressão de um desejo, quiçá, um sintoma social, pois, diz a autora (ibid), a imagem faz devir o sujeito que a produz, ela é duas coisas em uma: uma operadora em uma relação e o objeto produzido por essa relação.

Em Junho de 2013, não havia ainda tramas narrativo-textuais claras. As imagens prevaleciam, na sua carência de sentido, na sua dinâmica pulsional. É por conta dessa dificuldade de encontrarem sentido em frases e imagens tão ambíguas que imprensa, 
partidos políticos e governos não reconheceram de imediato o aspecto político em pauta naqueles protestos. À deriva de um eixo explicativo unívoco e muito afeitos a programas partidários e projetos de poder, sequer atentaram para a pluralidade identitária, para o polimorfismo e a polissemia das ruas. Ilustrativa dessa afirmação, a declaração do presidente em exercício da Câmara Federal, André Vargas, do PT, em canais de televisão, de que era preciso esperar para ver o que queriam os manifestantes, é análoga à expressão corriqueira usada quando uma imagem tira o prumo: “estou sem palavras". É o reconhecimento da falência da instância simbólica, do fosso entre o imaginário que conforma o Eu e sua compreensão do real. Mas, ao mesmo tempo, a admissão da urgência do próprio símbolo.

Não é de admirar que a estética e a estilização corporal dos manifestantes que tomaram as ruas em 2013 também passassem ao largo das percepções apressadas, ainda que a ação política se situe na conjunção entre elaboração pulsional, produção imagética e dinâmica identitária. É que o imaginário faz o laço social pela pulsão escópica. A rigor, ver e dar-se a ver confluem, são partes de uma só dinâmica pulsional que traduz tanto as diferenças quanto as semelhanças intersubjetivas.

No fundo, corpos desnudados, rostos pintados, cartazes irônicos, performances, comportamentos histéricos, essas imagens iluminavam outras cenas não necessariamente situadas em junho de 2013, pois toda imagem marca uma presença que implica uma ausência. Ao mostrar algo, a imagem encobre a visão de outros elementos subsumidos no olhar. Ao presentificar uma cena é outra cena que ela, a imagem, visa a obliterar, mas que, no fundo, só consegue realçar: uma ausência encoberta, uma lembrança que pretende encobrir outra. Em psicanálise, a ideia de lembrança encobridora, uma hipótese de uma imagem estratégica na memória, conforme Didi-Huberman (2010) explica o conceito de Freud, está ligada à pretensão de que o essencial de uma realidade (a cena primária) seja esquecido. Resta que a tentativa de não revelar a cena primária produz fantasias visuais não muito claras, mas passíveis de interpretação: um sintoma emerge da cena representada imageticamente. E a chave para compreender os sintomas, como pontuou Freud, está no processo de rememoração da cena, e esse, de todo modo, é um processo ligado à imaginação e às suas correlatas cadeias de significantes, para usar uma expressão de Lacan. Uma indicação metodológica se pode depreender da ideia de sintoma: o trabalho analítico consiste no "despertar de reminiscências", que é nada mais do que um processo, como se disse, imaginativo-simbólico. Pensado assim, esse processo inverte a todo instante a relação, que se pretendia unidirecional, entre o simbólico e o imaginário: nesse caso, não é apenas o 
simbólico que está a conferir significados ou sentidos às imagens, mas a renovação constante das reminiscências imagéticas que exige do simbólico o uso de reconfigurações semânticas atualizáveis.

Em atos cenográficos, a inversão da ordem, pela via da carnavalização dos protestos, o uso do riso e do humor, para promoção da crítica social, e o apelo erótico no trato ao corpo provocavam os manifestantes de 2013 a não dançarem conforme a música tocada. Essa subversão histérica que transcendia o espaço privado para dar-se a ver publicamente nas ruas só podia ser entendida como forma de chamar a atenção, como estratégia para se posicionar e se visibilizar no mundo social e, sobretudo, como sintoma, uma chave de leitura de desejos reprimidos e recalcados e de cenas e acontecimentos, senão traumáticos, pelo menos configuradores de uma economia psíquica. Em outras palavras: os corpos-imagens performáticos lidavam com o desejo de maneira figurativizada para denunciar as repressões e o recalque às pulsões.

Não tardou, porém, para que uma ordem simbólica fosse convocada, encerrando o transe, 'dando nome aos bois', 'colocando cada um no seu quadrado' e 'inscrevendo cada um na sua bolha': uma coesão de sentidos, de fato, produz efeitos de identificação grupal, ao operar a simbolização dos acontecimentos apagando a linha tênue entre o que se mostra claramente e as profundezas obscuras do mostrado. Desta forma, na urgência de sentido, uma domesticação do desejo e uma trama política de cunho identificatório se insinuavam no cenário nacional, preparando os eleitores para as modelizações que seriam ofertadas ao longo do período pré-eleitoral: o uso de imagens religiosas, no bojo de uma disputa político-partidária, podia ser interpretada como a anunciação da verdade revelada por Deus, a boa-nova anunciada por um único líder (ou futuro candidato) para o único povo eleito (ou eleitor?). A identidade (pelo menos aquela da ordem da política partidária) era agora uma questão de escolha, de idealizações opostas, de polarização de afetos e emoções, no limite de dois modelos apresentados: "nós contra eles", arregimentava anos antes o Presidente Lula, insurgindo-se contra elites, neoliberais e direitistas; "metralhar a esquerdalhada" ou "esses marginais vermelhos serão banidos da nossa pátria", generalizava a violenta retórica de Bolsonaro contra o lulismo, o petismo, o comunismo, as minorias. Em curso, uma identidade vetorizada pela atividade nominativa segregadora. $\mathrm{O}$ sol do Brasil não é para todos: Deus ou o Diabo.

\section{$4^{a}$. CENA: OU COXINHAS OU MORTADELAS}


Inconteste, a ideia de que o imaginário é gregário recupera a discussão sobre o poder relacional das imagens. Por conseguinte, assume-se que a imagem conecta temporalidades e aproxima espaços pela experiência imaginativo-mnemônica dos sujeitos. A partilha do tempo e do espaço é uma ação estético-política, pois se realiza pela imagem. Tal convicção está clara no pensamento de Benjamin (2006) quando se refere à aura como uma trama singular de espaço e tempo ou como aparição de uma coisa longínqua, por mais próxima que possa estar. Corroborando a ideia de Benjamin, Didi-Huberman (2010, p.148) afirma que "o objeto aurático supõe assim uma forma de varredura ou de ir e vir incessante, uma forma de heurística na qual as distâncias - as distâncias contraditórias - se experimentariam uma às outras, dialeticamente.” A imagem dialética traz o longe para perto e empurra o perto para longe, suprime as distâncias e subverte o tempo lógico, com isso criando um movimento que integra todas as temporalidades, um tempo único, mas cheio de variações, singular, fulgurante, da espera, da mostração, da contemplação, da expectativa, do desejo - do inconsciente.

Benjamin (2006) falava de imagens dialéticas como criptas do social, numa alusão ao poder das imagens de embaralhar as temporalidades e suscitar uma legibilidade histórica, uma espécie de restituição da história ou, em outras palavras, o exercício de uma restituição do que não foi ainda revelado (Didi-Huberman, 2015b): uma história-outra tornada visível pela leitura do que, dialeticamente, a imagem revela e não revela. Nestes rastros de um tempo anterior, pelos resquícios de caráter imagético, ver além do imaginário, portanto, é ir além das próprias imagens que o conformam, é ver além do mostrado, é esperar algo dos restos não simbolizados. Eis, portanto, um exercício de historiografia. Pela via do imaginário, tomado também como sintoma.

Leitor atento de Freud, que dizia que não há passagem de tempo para as formações do inconsciente, Benjamin postula a formação de um inconsciente ótico e assim se aproxima da temporalidade a posteriori ou invertida empregada pela psicanálise para a interpretação do sintoma, no qual um sentido só se forma pela criação permanente de articulações temporais. Pensadas dessa forma, as imagens seriam indícios de uma perda, de algo além do que se mostra. Injunção epistemológica, que se desdobra em questões relativas ao método, infere-se que o imaginário, compreendido à parte do tempo lógico, produz sentidos em cadeias de significação que relacionam restos e resíduos do passado, imagens que resistem à datação estanque de uma evolução cronológica. Justamente ali, onde um tempo perdido se presentifica pela contemplação da imagem, que faz o olhar voltar-se ao passado, é que se torna possível vislumbrar a possibilidade de um presente- 
outro e de um porvir indeterminado. Toda imagem, antes de mais, é um significante que traz à baila um conjunto de relações. Como suplemento de uma falta, o significante só pode produzir e dinamizar essa ausência ou perda, uma vez que a imagem não corresponde só ao objeto que representa nem à cena que evoca. A despossessão comum do objeto funda o laço social pela via de um substitutivo, que é a imagem compartilhada (Marie-José Mondzain, 2017). Portanto, o que está além da imagem é justamente o imaginário: o exercício ou investimento pulsional com a pretensão de restauração ou presentificação de algo que, a rigor, é impossível de ser restaurado, mas que pode ser compreendido.

Contudo, se a dialética da imagem cede ao fechamento e à indiscutível autenticidade do símbolo, o imaginário dá vazão a processos de identificação que podem revelar uma tendência conservadora, na medida em que seu poder de agregação se torna o apanágio para legitimar relações de poder, domínio, exclusão, afirmar estereótipos, aprofundar divisões e referendar tradições que servem aos interesses de grupos. Para manter a potência criativa do imaginário, preservar seu poder alegórico e, sobretudo, valorizar o aspecto aurático das imagens, é necessário denunciar as estratégias ideológicas de legitimação dos significados compartilhados e, a partir daí, proceder a um exercício de desnaturalização do simbólico. A aura, embora pensada por Benjamin no bojo de estudos teológicos, estaria na contramão dos símbolos religiosos e de suas práticas idólatras que se fundam na crença consensual gerada pela contemplação de uma imagem. Cumpre, então, recolocar as imagens num patamar ontológico, por muito tempo negado pela filosofia ocidental, compatível com seu vigor para produzir variações da realidade.

Gottfried Boehm (2017) explica que as imagens foram excluídas do logos por causa de sua equivocidade, pois ao contrário de fazer uso das regras do modelo do sentido autêntico, baseado na predicação, as imagens dão acesso a 'um pensamento com os olhos'. Eis o processo de naturalização mencionado: na relação do imaginário com o simbólico, uma sede de verdade procura ofuscar os múltiplos vetores de sentido lançados pelas imagens. O que dizer da identidade, por exemplo, pensada no âmbito da suposta veracidade do sentido e do princípio da não-contradição? Também ela, nesse escopo lógico, mantida sob o sigilo das ambiguidades e antíteses do imaginário, pode assumir um estatuto unívoco no simbólico, tornando-se livre de qualquer embaraço interpretativo: ou se está de um lado ou do outro. Ou se é coxinha ou se é mortadela.

A imagem de coxinhas versus mortadelas expressa uma (micro) coesão e uma (macro) divisão. No nível interno, essa divisão cria um grupo por coesão de sentimentos, afetos e paixões e, para fora do grupo, o opõe e o faz rivalizar com outro grupo criado no 
mesmo processo. Nessa imagem, quase nenhuma contradição, a não ser a da biporalidade de encaixe dos sujeitos. Predicação plena, pretensão insistente pelo sentido absoluto, compulsão pela verdade: coxinha ou mortadela, nada além, nada aquém, nada entre. Ação política com requintes de marketing eleitoral, está-se diante de uma imagem estanque, condensada em significados supostamente indubitáveis, que posiciona os sujeitos em categorias díspares, ousando apagar a complexidade das dinâmicas híbridas de produção de identidades individuais e coletivas. Coxinhas versus mortadelas, como se não houvesse nuances e gradações entre tantos que se enquadram nessa dissenção tão reificadora e maniqueísta, representa a vetorização da identidade política e seu acoplamento perfeito a uma classificação dualizada. Daí para a violência, como diz Sérgio Abranches (2019), basta uma série de afirmações inconsequentes de líderes que encarnam essas diferenças identitárias.

\section{5 . CENA: QUEM PAGA O PATO DANÇANTE?}

Muitas vezes, por força das instâncias técnicas de produção e divulgação de imagens e de reforço do conteúdo das mesmas, a ambiguidade identificatória do imaginário (imagens do Eu e do Outro) é arrancada de sua complementaridade fundante, reduzindo-se ao antagonismo de relações de classe, de gênero, de posicionamento político etc. Francisco Bosco (2018) explica que há imagens que acenam com sua suposta completude, que excluem a falta, que apelam à identificação em termos rivalitários, impedindo o sujeito de fugir da identificação forçada e de compreender a estrutura das relações subjetivas. Quando isso acontece, o imaginário quase sempre reitera realidades já instituídas.

Cornelius Castoriadis (1995) analisa o imaginário a partir da relação entre o que é instituído e instituinte. Sobre isso, Camila Sampaio (2000) afirma: “...quando a potência instituinte do imaginário não é ativada e alimentada, o instituído toma seu lugar, reproduzindo, como realidade reiterada e repetitiva, uma significação imaginária um dia criada e criadora." Ainda assim, para Castoriadis (op.cit.), a imaginação pode ser a recusa e a renovação do instituído: imaginário como potência criadora, imaginação radical, resistência e criação frente à ordem dada.

De acordo com Tânia Swain (2019), o imaginário é uma atividade criadora circular que tanto cria a realidade como é por ela criado, sem que se possa hierarquizar o instituidor e o instituído. Nesta ótica, ainda segundo Swain (op. cit.), o imaginário cria realidades vivenciadas e, ao mesmo tempo, efetua leituras do social que passam a ser a matéria prima da produção imagética, pouco importando se as imagens tem aspecto iconográfico ou são criações mentais ou, ainda, se tem aspecto icônico ou são formadas em textos verbais e, 
correlatamente, em discursos, se traduzem certas materialidades ou foram produzidas de maneira fantasiosa. Martin Jay (1988) afirma que o imaginário não é imagem de alguma coisa, porém criação incessante e indeterminada (social-histórica e psíquica) de figuras/formas/imagens. Parece interessante recuperar a ideia de que um regime escópico traduz um particular comportamento da percepção visual (ibid.) e, cumpre acrescentar, uma singular operação desejante, um campo aberto para pensar a pulsão escópica, sua escolha objetal, sua participação no laço social e a formação do imaginário.

Não obstante a instituição e reiteração de representações, o imaginário resiste e se refaz. Na sua constante relação com o simbólico, por vezes os sentidos preteridos, as imagens obliteradas, os desejos recalcados retornam como sintomas, capazes de produzir releituras históricas que destoam dos enquadramentos instituídos. O imaginário consiste, e o simbólico insiste, diz Lacan. Nesse processo, ultrapassando o sincronismo estrutural, as imagens ficam em suspenso, à espera, e adquirem sentidos numa cadeia significante renovável que subverte o tempo lógico e elide fronteiras espaciais.

Apesar de preponderarem em certas épocas, as imagens não tem datação precisa, uma vez que estão enredadas numa dialética de temporalidades, e tampouco se limitam a contextos físicos. Elas se inserem em formas históricas de longa duração, mas eclodem intempestivamente, mantendo relações de reciprocidade, constituindo e ofertando certos sentidos com base em cadeias e associações significantes sempre atualizáveis pelos mecanismos da memória. Nessa passagem transformadora, de aspecto simbólico-matricial, ultrapassam, contudo, o formalismo, o sincronismo e a imobilidade das estruturas e subvertem a relação linear entre passado, presente e futuro. Assim posto, o imaginário não se reduz a uma estrutura totalizante, formal e inalterável de associação ou relação sígnica. Nesse caso, parece prudente manter do Estruturalismo a ideia de que o sentido se forma numa relação, sem que essa seja baseada em binarismos e oposições imutáveis e prédeterminadas, evitando-se assim que produza efeitos de totalização compreensiva rumo ao perigo do conhecimento absoluto.

Tampouco o imaginário constitui uma sucessão cumulativa de imagens e padrões visuais, encetada numa cronologia. O imaginário é um processo formado também por rupturas, descontinuidades e permanências, por encobrimentos e revelações, por contradições, hiatos, lacunas, e diz respeito a uma potência ou atividade imaginativomnemônica que opera com as formações visuais disponíveis em distintos momentos da história pessoal e coletiva. O imaginário traduz a relação complementar entre lembrar e 
esquecer, mostrar e esconder, e se conforma a um regime escópico que produz objetos desejados pelo olhar ou que produz um tipo de desejo de olhar para algo.

O imaginário é aquilo que não se revela somente na imagem, é também o que se revela num para além dele mesmo, no processo de transmutação para o simbólico, na passagem da ilusão de unidade para a fantasia constituída na relação dual (com o outro) e plural (com o social, a cultura e a política). O imaginário perfaz e performa uma relação; ele é o que sobra, o que escapa, o que está para além da imagem, portanto, aquilo que não está apenas na imagem, porque a partir dela é que se provocam a imaginação, a fantasia, a memória, o desejo. Nisso reside o aspecto alegórico, a feição dialética e a dimensão histórica do imaginário: fazer aparecer outra imagem de passado que a cultura obliterou, trazer à tona as variações dos possíveis.

Contudo, a potência imaginativa e instituinte de Junho de 2013 é ofuscada no momento em que, apossando-se de imagens que carregam o peso de uma completude forçada, o simbólico ilumina apenas um único sentido ofertado, expressamente a partir do instante em que coxinhas, mortadelas, patos e dançarinos-autômatos com coreografias ensaiadas e previsíveis tomam as ruas do país, repetem uma retórica antiga nos meios de comunicação de massa e assumem o protagonismo das mídias sociais. Instituído na repetição insistente de alguns significantes e na edificação de identidades fixas e excludentes, esse processo conduz à adesão individual acrítica, irascível, baseada numa polarização afetiva que revela um espírito de time no qual: a) o abjeto já não traz repulsa, indignação ou assombramento (exemplos: os gestos do candidato Bolsonaro com - ou emulando - arma de fogo; as estampas com a degola do Ex-Presidente Lula; as insistentes cenas e imagens do atentado a faca ao candidato Bolsonaro em um evento de campanha; b) são enfatizados antagonismos e preconceitos, numa seca e totalizadora injunção significante.

O comportamento obsessivo observado a posteriori, sobretudo na eleição de 2018, está calcado na instituição simbólica do imaginário, no recalque às pulsões, na inibição das fantasias e dos atos corporais de conotação erótica (agora coreografados e mutilados na imagem de um pato assexuado e inexpressivo que exige a indicação urgente de um culpado) manifestados em junho de 2013. Passa-se gradualmente de uma visível demanda por atenção e aceitação, em 2013, para o engessamento do desejo pela normatização e pela normalização impostas, até as eleições de 2018.

Como as imagens operam um laço, lá onde falta algo, se há uma relação intersubjetiva, essa é da ordem da pulsão escópica, do ver e dar-se a ver, portanto, da 
imagem, do Eu, da alteridade, enfim, do imaginário. Ora, sendo o imaginário o lugar da completude ilusória, o sujeito do imaginário só pode ser o sujeito da ilusão narcísica, absoluto, completo, pleno, bastante a si mesmo, sujeito-devir da identificação simbólica. Pois é nesse ponto, na passagem para o simbólico, que se completa uma operação política: o imaginário nomeado, enquadrado, esvazia-se de todo sentido possível e assume uma cara, um corpo, uma ideia, enfim, um nome.

\section{6ª CENA: EM TERRA DE CEGO, QUEM VÊ NÃO OLHA}

Em 29 de setembro de 2018, na semana anterior ao primeiro turno das eleições presidenciais, o olhar passeia por imagens conhecidas. Em certos momentos, desvela-se uma estrutura do imaginário: um manifestante usa uma camiseta estampada com o rosto de Che Guevara; outro segue caminhando e cantando uma música que o tempo se encarregou de eternizar. A poucos metros dali, uma pichação traz de volta Maio de 68: as paredes têm olhos, ouvidos e boca também. Do outro lado, manifestantes pró-Bolsonaro aludiam à "ameaça comunista" e ao "perigo vermelho", voltando ao contexto da Guerra Fria dos anos 60 (Abranches, 2019). Parece que o imaginário é uma infinda repetição, uma cadeia a produzir sentidos unissonantes e eternos. O olhar continua seu percurso, sob os gritos de Ele Não. Retornam imagens de outro tempo.

São imagens históricas, dialéticas, exatamente porque desafiam o exclusivismo de pertencer a uma dada época. Acionadas no instante, reviram o passado, iluminam o presente, resignificam o mundo. Elas contem muitos significados, se pensadas como um sintoma que reverbera o presente no passado e vice-versa. Algumas delas poderiam ser vistas como denúncia da simbolização das paixões e do adornamento dos desejos: não seria o caso de pensar que os simpatizantes do então candidato Jair Bolsonaro, ao fazerem a saudação nazista em protestos de rua, dão a ver o sintoma de uma pertinaz obsessão e expõem mais sobre eles, os sujeitos, do que sobre o conteúdo do gesto executado?

O imaginário forma um fluxo incessante e até inesperado de novas associações, montagens, remontagens (entre imagens) e de rememorações e releituras (pelos sujeitos). As imagens são uma presença. E instituem uma relação - entre imagens, entre sujeitos, pelo desejo. Eis, portanto, seu domínio intersubjetivo e sócio-cultural, sua coautoria e seu espaço de inteligibilidade ontológica. Neste sentido, é necessário perceber em cada uma das imagens aludidas um excedente - de olhar, de identificação, de gozo. Talvez um sintoma, revelado e atualizado no presente, mas calcado em acontecimentos passados. 
Pensadas nesse sistema pulsional, as imagens declinam a relação dos sujeitos com as cadeias de significação, revelando o modo como querem significar o real, uma vez que esperam uma síntese simbolizante. Nesse inevitável diálogo entre o imaginário e o simbólico, algo se perde. A suplência das imagens equivale ao seu próprio excedente: o que está além delas é exatamente o que lhes falta quando inseridas num sistema de interpretação. Eis sua dinâmica: as imagens buscam no simbólico o sentido suposto para a supressão de uma falta. Nisso, assumem uma conotação política. Como diz Mondzain (2017), as instituições políticas sempre tiveram o cuidado de interditar e controlar a produção de imagens, uma vez que perceberam que a capacidade do sujeito de produzir imagens faz parte da economia constituinte do desejo. Para a autora, é a falta de um objeto e sua demanda orientada à produção imaginativa que explica a feição intersubjetiva das imagens: "o desejo que anima a circulação de signos só se sustenta com a separação entre sujeitos que trocam esses signos na ausência das coisas em si." (ibid. p. 47) Ou seja: a imaginação é pura energia política, pois a partilha de imagens, segundo ela, é a via pela qual se constitui, pelo desejo, o objeto político de uma demanda insaciável, um desejo do objeto. Questiona: qual o destino político do pulsional, da simbolização das paixões?

Ao referir-se às imagens dialéticas das quais falava Benjamin, Didi-Huberman (2010) afirma que, de fato, há uma estrutura em obra nas mesmas, desde que não se entendam essas imagens como formações estanques, estáveis e regulares. Ao contrário, são formas em formação, transformações. As imagens dialéticas, como processo, fazem apreender a estrutura e ao mesmo tempo criam um estado de choque, um lapso, algo inexprimível, que "forçará a ordem do discurso ao silêncio da aura." (ibid. p.173) Silêncio, aqui entendido, como qualquer oferta de sentido ou como nenhuma simbolização definitiva. Com as imagens dialéticas, pode-se pensar uma teoria da história que seja ao mesmo tempo um tratado de estética e política na sua ligação com a memória subjetiva: "não há imagem dialética sem um trabalho crítico da memória, confrontado a tudo que resta como ao indício de tudo o que foi perdido." (ibid. p. 174)

Sim, algo vem se perdendo desde junho de 2013 - e se perderá ainda, sempre. Se um núcleo duro e coeso de sentidos, dali para frente, procurou encerrar a orbital de possibilidades dos acontecimentos, reconhecer esse desvio, contudo, é um ganho de inteligibilidade histórica, pois indica os rumos e as variações das pulsões e do desejo, mesmo quando administrados pelas instituições. O imaginário acontece, é pura presença, é também memória. Haverá uma abertura no imaginário, um resto não simbolizado, uma espiral de possibilidades? Outro modo de olhar e ler a mesma imagem? 


\section{CENA: “O PRESENTE É UM PRESENTE"}

Mas eis que as imagens são dinâmicas e aprofundam a rebeldia e a resistência dos possíveis. A presentificação da imagem - e da aura - não é uma questão só de espaço, mas de tempo, é uma necessidade do aqui e do agora. Presentificar é fazer viver no agora.

O presente é um presente é uma pichação emblemática. Desde 2013, ela continua sendo inscrita em vários locais da cidade de Teresina, sempre com uma grafia única, na cor preta, a reproduzir uma identidade sígnica e autoral (anônima, claro) e a brincar com os sentidos pelo aspecto plurissemântico da palavra PRESENTE. Estando em muitos lugares, a imagem da pichação acompanha o sujeito aonde ele for, pois é uma imagem que já está inscrita na memória. Se o sujeito lembra, ele também vive o e no instante, sem precisar se deslocar pelos espaços físicos, ele também está disperso, mas ao mesmo tempo atento, aberto, livre, para, com isso, promover outro tipo de deslocamento: aquele que se dá nos sentidos produzidos nas cadeias de significação. Pichação onipresente, viva na memória, imagem aurática, a desafiar a cronologia e os muros de fronteira, ela aponta para lugar nenhum, para um tempo sem variáveis, um presente onde todos os espaços e todas as temporalidades se integram, afinal, o que é alegórico é o próprio tempo.

É no não mostrado e no não dito que residem a criação, a dispersão e a diversidade. É preciso desejar o que não aconteceu. É preciso imaginar para sobreviver. É preciso lembrar para criar o eterno novo. Que grande presente!

O imaginário, no presente, pode apontar a direção dos possíveis, as variações da realidade. Uma nova espiral de possibilidades está acionada. À cata dos inomináveis da história, à espera de algo que aconteça, transcendendo a ideia de fluxo linear, o imaginário se torna alegórico, uma instância entre o sentido e o verbo. Ele diz algo quando também silencia. Talvez o imaginário possibilite pensar numa história do que NÃO aconteceu? Uma história-outra que não se anuncia presentificada? Um porvir da história ou uma história por vir?

\section{REFERÊNCIAS}

ABRANCHES, Sérgio. Polarização radicalizada e ruptura eleitoral. In ABRANCHES, Sérgio et. ali. Democracia em risco? - 22 ensaios sobre o Brasil hoje. São Paulo: Companhia das Letras, 2019.

ALBUQUERQUE, H.; GUTIÉRREZ, B.; MORAES, A.; PARRA, H.; SCHAVELZON, S.; TIBLE, J. (orgs). Junho: Potência das ruas e das redes. São Paulo: Friedrich-Ebert- 
Stiftung, 2014. <http://library.fes.de/pdf-files/bueros/brasilien/11177-20150226.pdf> (Último acesso em 22/06/2018)

BACZKO, Bronislaw. Los imaginários sociales: memorias y esperanzas coletivas. Buenos Aires: Ediciones Nueva Visión, 1991.

BENJAMIN, Walter. Selected Writings (4 vols). Boston: Harvard University Press, 2006. BOEHM, Gottfried. Aquilo que se mostra. Sobre a diferença icônica. In: Pensar a imagem. Belo Horizonte: Autêntica Editora, 2017.

CASTORIADIS, Cornelius. A instituição imaginária da sociedade. 3. edição. Rio de Janeiro: Paz e Terra, 1995.

DIDI-HUBERMAN, Georges. Diante do tempo: história da arte e anacronismo das imagens. Belo Horizonte: Editora UFMG, 2015a.

Invenção da Histeria - Charcot e a iconografia fotográfica da Salpêtrière. Rio de Janeiro: Contraponto, 2015b.

O que vemos, o que nos olha. São Paulo: Editora 34, 2010.

ESPIG, Márcia. O conceito de imaginário: reflexões acerca de sua reflexões acerca de sua utilização pela História. In: Textura. Canoas n. 9 nov. 2003 a jun. 2004 p. 49-56

FREUD, Sigmund. Obras Completas - Volume 12. São Paulo: Companhia das Letras, 2010.

JAY, Martin. Scopic Regimes of Modernity, Vision and Visuality. Seattle: Bay Press, 1988

MACHADO, Leila Domingues; REGATTIERI, Lorena Lucas; LIMA, Haroldo Ferreira. Corpos luminosos, passageiros na noite. In: Esferas. Ano 4, no 7, Julho a Dezembro de 2015

MONDZAIN, Marie-José. A imagem entre providência e destinação. In: Pensar a imagem. Belo Horizonte: Autêntica Editora, 2017.

RANCIÈRE, Jacques. Le spectateur émancipé. Paris: La Fabrique, 2008.

SAMPAIO, Camila Pedral. O cinema e a potência do imaginário. In: BARTUCCI, Giovanna (Org.), p. 45-70. Psicanálise, cinema e estéticas de subjetivação. Rio de Janeiro: Imago, 2000. 264 p.

SILVA, R. H. A. da (Org). Ruas e Redes: dinâmica dos protestos BR. Belo Horizonte: Autêntica Editora, 2015.

SWAIN, Tânia Navarro. O Imaginário e a História... em quadrinhos. http://www.tanianavarroswain.com.br/brasil/imaginario\%20quadrinhos.htm (Último acesso em 20/08/2016) 
TEIXEIRA, A. Junho de 2013 à luz dos acontecimentos. Publicado no Blog Subversos. https:// blogdasubversos.wordpress.com/2014/03/19/junho-de2013-a-luz-dosacontecimentos/ (Último acesso em 16/10/2016) 